\title{
Prevalence and risk factors associated with anti-Toxoplasma gondii antibodies in sheep from Bahia state, Brazil
}

Prevalência e fatores de risco associados a anticorpos anti- Toxoplasma gondii em ovinos da Bahia, Brasil

Luciana Afonso Guimarães ${ }^{1}$, Rodrigo Alves Bezerra ${ }^{1}$, Daniele de Santana Rocha ${ }^{1}$, George Rêgo Albuquerque ${ }^{2 *}$

'Programa de Pós-graduaçăo em Ciência Animal, Universidade Estadual de Santa Cruz - UESC, Ilhéus, BA, Brasil

${ }^{2}$ Departamento de Ciências Agrárias e Ambientais, Universidade Estadual de Santa Cruz - UESC, Ilhéus, BA, Brasil

Received June 19, 2012

Accepted February 14, 2013

\begin{abstract}
In this study, we aimed to determine the prevalence of Toxoplasma gondii antibodies and identify risk factors associated with this infection in sheep from the southern region of Bahia state. Between February and December 2010, 795 sheep from 31 farms located in nine municipalities were tested. We found seroprevalence of $30.2 \%$ (240/795), with titers of 64 (38.3\%), 256 (34.2\%), 1,024 (18.3\%), and 4,096 (9.2\%) by Indirect Fluorescent Antibody Test (IFAT). Seropositive sheep were detected in all farms sampled. Univariate statistical analysis detected association between T. gondii seropositivity and the variables age, use of fresh food mainly, water source, stocking rate, production system, presence and number of cats on the farm, and transit of cats $(\mathrm{p}<0.05)$. In the logistic regression model, transit of cats $(\mathrm{p}=0.001)$, production system $(\mathrm{p}=0.007)$, and age $(\mathrm{p}=0.027)$ were identified as risk factors associated with T. gondii infection.
\end{abstract}

Keywords: Epidemiology, ovine, toxoplasmosis, zoonosis, risk factors.

\section{Resumo}

Objetivou-se com este estudo determinar a prevalência de anticorpos anti-Toxoplasma gondii e identificar os fatores de risco associados à infecção em ovinos no sudeste do Estado da Bahia. De fevereiro a dezembro de 2010, 795 ovinos de 31 propriedades localizadas em nove municípios foram analisados. A soroprevalência foi de 30,2\% (240/795), com títulos de 64 (38,3\%), 256 (34,2\%), 1.024 (18,3\%) e 4.096 (9,2\%) pela Reação de Imunoflorescência Indireta (RIFI). Ovinos positivos foram detectados em todas as fazendas estudadas. $\mathrm{Na}$ análise estatística univariada detectou-se associação entre a soropositividade e idade, uso de alimentação fresca, fonte de água, sistema de produção, presença e número de gatos na fazenda e o transito de gatos $(p<0,05)$. No modelo de regressão logística, transito de gatos $(\mathrm{p}=0,001)$, sistema de produçáo $(\mathrm{p}=0,007)$ e idade $(\mathrm{p}=0,027)$ foram identificados como fatores de risco associados à infecção por T. gondii.

Palavras-chaves: Epidemiologia, ovino, toxoplasmose, zoonose, fatores de risco.

\section{Introduction}

Toxoplasmosis is an important parasitic zoonosis of cosmopolitan distribution caused by the protozoan Toxoplasma gondii. Humans can be infected mainly through the ingestion of cysts in contaminated food (consumption of undercooked or raw meat) or sporulated oocysts in water (FERGUNSON, 2009). Cats play a fundamental role in spreading this agent because they are the definitive hosts (DUBEY; JONES, 2008; DUBEY, 2009).

The sheep industry is an economic activity in operation in every continent with different climates. The current Brazilian sheep flock

\section{${ }^{*}$ Corresponding author: George Rego Albuquerque}

Departamento de Ciências Agrárias e Ambientais, Universidade

Estadual de Santa Cruz - UESC, Rod. Ilhéus-Itabuna, Km 16, Salobrinho,

CEP 45662-000, Ilhéus, BA, Brasil

e-mail: gralbu@uesc.br is of approximately 16 million animals and $58.4 \%$ of these are in the northeastern region of the country. The state of Bahia is the second largest domestic sheep producer with 3,028,507 animals (BRASIL, 2009). Toxoplasma gondii is an important parasite of sheep, causing reproductive disorders such as embryonic death, abortion, stillbirth, and birth of weak animals (MASALA et al., 2003; DUBEY; JONES, 2008).

Antibodies to T. gondii have been found in sheep worldwide and seroprevalence rate ranges from $6.7 \%$ to $84.5 \%$ (KAMANI et al., 2010; KLUN et al., 2006). The seroprevalence of T. gondii infection in flocks of sheep in Brazil ranges from 7.0\% to $54.6 \%$ (MOURA et al., 2007; OGAWA et al., 2003). The only study in Bahia state with sheep was carried out in the metropolitan region of Salvador and Recôncavo, with prevalence of $18.75 \%$ (GONDIM et al., 1999). 
Risk factors such as age, contact with cats, breeding system, and water supply can be highlighted and have been previously identified in ovine toxoplasmosis in Brazil (ROMANELLI et al., 2007; PINHEIRO et al., 2009; LOPES et al., 2010; ROSSI et al., 2011). Considering the importance of toxoplasmosis and the lack of epidemiological information in the state of Bahia, the aims of this study were to determine the prevalence of T. gondii infection in sheep flocks from southern Bahia state and identify possible risk factors associated with the infection.

\section{Materials and Methods}

\section{Study population and blood collection}

The study was conducted from February to December 2010; it involved 795 animals from 31 farms, which are distributed in nine municipalities and enrolled in the Cooperative of Sheep and Goat Producers of Southern Bahia (COOPERVINO). A sample size of 650 animals was estimated by the statistical program EPI-INFO, version 3.5.1, considering a prevalence prospect of $50 \%$, with sampling error of $5 \%$ and confidence level of $99 \%$ for a population of 33,000 animals (BRASIL, 2009); however, a sample size larger than required was chosen.

The herd was primarily composed of animals of the Santa Inês breed or crossbreds. The age of the animals was estimated by monitoring dentition, and the animals were categorized in two age groups based on Carneiro et al. (2009): above and below 36 months. No blood samples were collected from lambs under six months of age due to the possible presence of colostral antibodies.

Blood was collected by jugular vein puncture and the serum was separated after centrifugation and stored at $-20{ }^{\circ} \mathrm{C}$ until use. The proposed study was approved by the ethics committee (CEUA-UESC 031/09).

\section{Questionnaire}

In order to determine risk factors, a structured interview with objective questions was conducted regarding the general characteristics of the farm, including the total area ( $\geq 100$ hectares or $<100$ hectares); breeding system (extensive or intensive); production type (family or commercial); size of the herd ( $\geq 100$ animals or $<100$ animals); stocking rate ( $\geq 1$ animal or $<1$ animal); cats owned by farmers (yes or no); transit of stray cats or wild felids (yes or no); number of cats ( $<3$ or $\geq 3$ cats); water source (trough or river/dam); source of water/food common to young and adult animals (yes or no); presence of pen (yes or no); cats with access to the animals' food and/ or water storage source (yes or no); use of fresh food mainly - grass (yes or no); gender (male or female); age ( $<36$ months or $\geq 36$ months); and animal breed (purebred or crossbred animals).

\section{Detection of antibodies}

Indirect fluorescence antibody test (IFAT) was performed to study anti-T. gondii antibodies. In this study, IFAT slides containing antigens of the RH strain of $T$. gondii were used. Negative and positive control serum $\left(1 \times 10^{6}\right.$ tachyzoites of $T$. gondii experimentally inoculated in a six-month-old lamb) were added to each slide and anti-sheep antibody conjugated to fluorescein isothiocyanate (F-7634, Sigma-Chemical, USA) were used. The IFAT cut-off value was 1:64 (FIGLIUOLO et al., 2004) and the positive samples were subjected to sequential dilutions until negative response.

\section{Statistical analysis}

To identify risk factors associated with infection by $T$. gondii, a bivariate analysis was carried out using Chi-square and Fisher's exact tests with significance level of 5\%, using the statistical program EPI-INFO, version 3.5.1. All variables with $\mathrm{p} \leq 0.2$ on bivariate analysis were subjected to collinearity analysis determined by the Spearman's rank correlation test according to BioEstat 5.0. Subsequently, multivariate logistic regression analysis was performed using EPIINFO, version 3.5.1.

\section{Results}

All farms used extensive breeding programs and no artificial breeding methods. Toxoplasma gondii antibodies were found in 240 (30.2\%) sheep, with titers of 64 (38.3\%), 256 (34.2\%), 1,024 (18.3\%), and 4,096 (9.2\%). All farms presented T. gondii-positive animals, with seropositivity varying from $6.3 \%$ to $100 \%$. Among the municipalities analyzed, Camacan presented the highest frequency of seropositive animals $(64.7 \%)$ and Itaju do Colônia presented the lowest frequency $(9.8 \%)$ (Table 1 ).

Table 1. Detection and distribution of anti-Toxoplasma gondii antibodies in sheep in some municipalities of the microregion Ilhéus-Itabuna, State of Bahia, Brazil.

\begin{tabular}{lccc}
\hline Municipalities & Number of examined & Number of Positive & Prevalence (\%) \\
\hline Camacan & 51 & 33 & 64.7 \\
Ibicaraí & 27 & 12 & 44.4 \\
Itacaré & 99 & 38 & 38.4 \\
Ilhéus & 179 & 60 & 33.5 \\
Itapé & 120 & 37 & 30.8 \\
Canavieiras & 159 & 38 & 23.9 \\
Pau Brasil & 73 & 12 & 16.4 \\
Itabuna & 26 & 4 & 15.4 \\
Itaju do Colônia & 61 & 6 & 9.8 \\
Total & 795 & 240 & 30.2 \\
\hline
\end{tabular}


Risk factors identified by bivariate and multivariate analyses are shown in Tables 2 and 3, respectively. In the bivariate analysis, seropositivity was observed in association with age, diet based on fresh food, production system, number of cats, water source, stocking rate, and transit of stray cats or wild felids. In the multivariate analysis, age, production system, and transit of stray cats or wild felids were identified as risk factors in this study.
Regarding age, $32.6 \%$ of animals over 3 years old were identified as positive, while $25.2 \%$ of animals under 3 years old were positive $(\mathrm{OR}=1.43)$.

The number of cats was an important factor: farms with more than three cats presented more positive sheep (35.3\%) than farms with one or two cats $(27.8 \%)(p=0.03)$. The transit of cats or wild felids in farms was a determining factor, as evidenced by the

Table 2. Bivariate analysis of risk factors associated with the presence of Toxoplasma gondii in sheep flocks of southern Bahia.

\begin{tabular}{|c|c|c|c|c|c|c|c|c|}
\hline \multirow{3}{*}{ Variables } & \multicolumn{4}{|c|}{ Animals } & \multirow{3}{*}{$\chi^{2}$} & \multirow{3}{*}{ P value } & \multirow{3}{*}{ OR } & \multirow{3}{*}{ CI 95\% } \\
\hline & \multicolumn{2}{|c|}{ Positive } & \multicolumn{2}{|c|}{ Total } & & & & \\
\hline & n & $\%$ & $\mathbf{n}$ & $\%$ & & & & \\
\hline Age group & & & & & 4.17 & 0.041 & 1.43 & $1.02-2.00$ \\
\hline$\geq 03$ years & 175 & 72.9 & 537 & 67.5 & & & & \\
\hline$<03$ years & 65 & 27.1 & 258 & 32.5 & & & & \\
\hline Breed & & & & & 0.28 & 0.596 & 0.91 & $0.67-1.23$ \\
\hline Purebred & 128 & 53.3 & 411 & 51.7 & & & & \\
\hline Crossbred & 112 & 46.7 & 384 & 48.3 & & & & \\
\hline Gender & & & & & 0.03 & 0.870 & 0.93 & $0.57-1.51$ \\
\hline Male & 26 & 10.8 & 90 & 11.3 & & & & \\
\hline Female & 214 & 89.2 & 705 & 88.7 & & & & \\
\hline Farmers have cats & & & & & 1.68 & 0.195 & 1.29 & $0.90-1.86$ \\
\hline Yes & 190 & 79.2 & 604 & 76 & & & & \\
\hline No & 50 & 20.8 & 191 & 24 & & & & \\
\hline Quantity of cats & & & & & 3.52 & 0.030 & 1.41 & $1.00-1.99$ \\
\hline$\geq 03$ & 104 & 54.7 & 295 & 48.8 & & & & \\
\hline$<03$ & 86 & 45.3 & 309 & 51.2 & & & & \\
\hline Cats with access to the water source & & & & & 0.41 & 0.520 & 0.86 & $0.59-1.27$ \\
\hline Yes & 140 & 72.5 & 455 & 74.5 & & & & \\
\hline No & 53 & 27.5 & 156 & 25.5 & & & & \\
\hline Transit of stray cats or wild felids & & & & & & 0.0001 & 2.14 & $1.56-2.94$ \\
\hline Yes & 104 & 43.3 & 250 & 31.4 & & & & \\
\hline No & 136 & 56.7 & 545 & 68.6 & & & & \\
\hline Production system & & & & & 5.34 & 0.020 & 1.62 & $1.09-2.42$ \\
\hline Familiar & 56 & 23.3 & 523 & 65.8 & & & & \\
\hline Commercial & 184 & 76.6 & 272 & 34.2 & & & & \\
\hline Mostly fresh food & & & & & 1.40 & 0.235 & 0.81 & $0.58-1.12$ \\
\hline Yes & 239 & 99.6 & 781 & 98.2 & & & & \\
\hline No & 1 & 0.4 & 14 & 1.8 & & & & \\
\hline Presence of Pen & & & & & 2.30 & 0.129 & 0.76 & $0.55-1.06$ \\
\hline Yes & 185 & 77.1 & 625 & 78.6 & & & & \\
\hline No & 55 & 22.9 & 170 & 21.4 & & & & \\
\hline Stocking rate & & & & & 3.61 & 0.057 & 0.72 & $0.52-0.99$ \\
\hline$<1$ & 140 & 58.3 & 404 & 50.8 & & & & \\
\hline$\geq 1$ & 100 & 41.7 & 391 & 49.2 & & & & \\
\hline Water source & & & & & 1.23 & 0.267 & 0.83 & $0.61-1.13$ \\
\hline Trough & 123 & 51.3 & 382 & 48.1 & & & & \\
\hline River, dam & 117 & 48.8 & 413 & 51.9 & & & & \\
\hline Water source common* & & & & & 0.01 & 0.001 & 1.05 & $0.58-1.88$ \\
\hline Yes & 223 & 92.9 & 737 & 92.7 & & & & \\
\hline No & 17 & 7.1 & 58 & 7.3 & & & & \\
\hline Food source common* & & & & & 0.01 & 0.001 & 1.05 & $0.58-1.88$ \\
\hline Yes & 223 & 92.9 & 737 & 92.7 & & & & \\
\hline No & 17 & 7.1 & 58 & 7.3 & & & & \\
\hline
\end{tabular}

*young and adult animals; \% - percentage; $\chi^{2}$ - Chi-square; OR - Odds ratio; CI - confidence interval. 
Table 3. Multivariate analysis of risk factors associated with the presence of Toxoplasma gondii in sheep flocks of southern Bahia.

\begin{tabular}{lccc}
\hline \multicolumn{1}{c}{ Variable } & OR & CI 95\% & $\boldsymbol{P}$ Value \\
\hline $\begin{array}{l}\text { Production system } \\
\quad \text { Family }\end{array}$ & 1.00 & & \\
$\quad$ Commercial & 1.50 & $1.02-2.21$ & 0.0385 \\
Transit of stray cats or wild felids & & & \\
$\quad$ Yes & 2.18 & $1.58-3.01$ & 0.0001 \\
$\quad$ No & 1.00 & & \\
Age group & 1.47 & $1.05-2.07$ & 0.0267 \\
$\quad$ >03 years & 1.00 & \\
$\quad<03$ years & & \\
\hline Final Log-Likelihood: 941.5040; OR - Odds ratio; CI - confidence interval.
\end{tabular}

multivariate analysis, and increased the probability $(\mathrm{OR}=2.14)$ of sheep infection.

By the bivariate analysis, it was possible to observe that the commercial production system used in the farms presented higher seropositivity $(\mathrm{OR}=1.61)$ when compared to the family production system, which is possibly due to the higher ingestion of oocysts in a contaminated environment. The family production system was characterized by only the family taking care of the animals - subsistence, while the commercial production system has employees and aims at the commercialization of animals.

\section{Discussion}

Toxoplasma gondii prevalence found in this study is similar to that described by Ueno et al. (2009), in Federal District (38.2\%) and by Pinheiro et al. (2009), in Pernambuco (32.9\%); higher than that found by Soares et al. (2009), in Rio Grande do Norte (20.7\%) and Langoni et al. (2011), in São Paulo (18.61\%); and it lower than that found by Lopes et al. (2010), in São Paulo (52\%) - all Brazilian states. All studies aforementioned used the IFAT for serology investigation. The differences observed may be due to climatic variations, age, type of animals and cut-off values used in the different studies.

All farms presented T. gondii-positive animals, showing that T. gondii is widely disseminated in sheep flocks in the studied region.

Among the municipalities studied, Camacan presented the highest frequency of $T$. gondii-positive animals (64.7\%), and Itaju do Colônia (9.8\%) showed the lowest frequency. Camacan and Itaju do Colônia belong to the same microregion; however, Camacan municipality has higher relative humidity (above $80 \%$ in average) due to the presence of the Atlantic Forest, which is used for cacao farming, thus favoring the maintenance of oocysts in the environment. In contrast, the municipality of Itaju de Colônia has replaced cacao farming by cattle raising and is no longer forested. It is also characterized by dry season (monthly rainfall of less than $60 \mathrm{~mm}$ ) between the months of June and September, and higher average temperatures, which could explain the lower prevalence of $T$. gondii.

By multivariate statistical analysis, it was possible to observe that commercial production presented higher seropositivity $(\mathrm{p}=0.03)$ compared to the family system. Commercial systems showed greater density of animals in an environment contaminated with oocysts and, therefore, more infected animals. CaballeroOrtega et al. (2008) found that flocks with more than 320 animals had more sheep infected with T. gondii compared to flocks with fewer animals.

There was no significant association between $T$. gondii infection and gender, confirming the data found by Soares et al. (2009) and Pinheiro et al. (2009). This result differs from those reported by Ramzan et al. (2009) and Van Der Puije et al. (2000), who observed that females were more affected than males, which was probably due to the lower immunologic resistance of females in some periods of their lives.

With regard to age, Pinheiro et al. (2009) and Clementino et al. (2007) found results similar to those of this study. We found that seroprevalence increases with age, suggesting that most animals acquire post-natal infection and according to Dubey and Kirkbride (1989) animals over three years of age have longer exposure to sporulated oocysts and increased risk of infection.

Stray cats and wild felids are most commonly found in almost all areas where sheep are kept, thus explaining the higher seroprevalence $(\mathrm{p} \leq 0.0001)$ in farms with these animals. Similar results were found by Vesco et al. (2007), Pinheiro et al. (2009), and Lopes et al. (2010). In the studied region, the presence of stray cats and wild felids is common due to the neighboring forest area for cocoa production.

Ingestion of oocysts from the environment and congenital transmission are the two main routes of $T$. gondii transmission in sheep. The proportion of prenatal and post-natal infection in these animals is often unknown, but epidemiological data indicate that most animals are infected after birth by horizontal transmission via ingestion of sporulated oocysts (BUXTON et al., 2006). Sporulated oocysts survive for long periods of time in favorable environmental conditions, such as humid soil (DUBEY, 2009), and this is the case of most of the municipalities studied.

The results showed the presence of $T$. gondii infection in sheep flocks in the microregion of Ilhéus-Itabuna, where mutton is increasingly popular as an animal protein source. As a result, it is a potential source for human toxoplasmosis. Control and prophylactic measures such as avoiding the presence of stray cats or wild felids in areas where sheep are raised, excluding this felids from where products used in sheep feed are stored, and decreasing the stocking rate of pastures should be adopted to improve the production system. Health programs for farmers, along with the dissemination of information about the means of transmission of this parasite, should be implemented.

\section{Acknowledgements}

The authors thank Fundação de Amparo à Pesquisa do Estado da Bahia (FAPESB) and Coordenação de Aperfeiçoamento de Pessoal de Nível Superior (CAPES) for the financial support.

\section{References}

Brasil. Ministério da Agricultura, Pecuária e Abastecimento. Censo Agropecuário. IBGE; 2009 [cited 2010 Jan. 10]. Available from: http:// www.sidra.ibge.gov.br/bda/pecua/default.asp?t=2\&z=t\&o=24\&u1=1\& $\mathrm{u} 2=1 \& \mathrm{u} 3=1 \& \mathrm{u} 4=1 \& \mathrm{u} 5=1 \& \mathrm{u} 6=1 \& \mathrm{u} 7=1$. 
Buxton D, Rodger SM, Maley SW, Wright SE. Toxoplasmosis: The possibility of vertical transmission. Small Rum Res 2006; 62(1-2): 43-46. http://dx.doi.org/10.1016/j.smallrumres.2005.07.037

Caballero-Ortega H, Palma JM, García-Marquez LJ, GildoCardenas A, Correa D. Frequency and risk factors for toxoplasmosis in ovines of various regions of the State of Colima, Mexico. Parasitology 2008; 135(12): 1385-1389. PMid:18801208. http://dx.doi. org/10.1017/S0031182008004873

Carneiro ACAV, Carneiro M, Gouveia AMG, Vilas-Boas LS, Vitor RWA. Seroprevalence and risk factors of sheep toxoplasmosis in Minas Gerais, Brazil. Revue Méd Vét 2009; 160(11): 527-531.

Clementino MM, Souza MF, Andrade Neto VF. Seroprevalence and Toxoplasma gondii-IgG avidity in sheep from Lajes, Brazil. Vet Parasitol 2007; 146(3-4): 199-203. PMid:17418950. http://dx.doi. org/10.1016/j.vetpar.2007.02.036

Dubey JP. Toxoplasmosis in sheep - The last 20 years. Vet Parasitol 2009; 163(1-2): 1-14. PMid:19395175. http://dx.doi. org/10.1016/j.vetpar.2009.02.026

Dubey JP, Jones JL. Toxoplasma gondii infection in humans and animals in the United States. Int J Parasitol 2008; 38(11): 1257-1278. PMid:18508057. http://dx.doi.org/10.1016/j.ijpara.2008.03.007

Dubey JP, Kirkbride CA. Enzootic toxoplasmosis in sheep in NorthCentral United-States. J Parasitol 1989; 75(5): 673-676. PMid:2795369. http://dx.doi.org/10.2307/3283047

Fergunson DJP. Toxoplasma gondii: 1908-2008, homage to Nicolle, Manceaux and Splendore. Mem Inst Oswaldo Cruz 2009; 104 (2): 133-148. http://dx.doi.org/10.1590/S0074-02762009000200003

Figliuolo LPC, Kasai N, Ragozo AMA, Paula, VSO, Dias RA, Souza SLP, et al. Prevalence of anti-Toxoplasma gondii and anti-Neospora caninum antibodies in ovine from São Paulo State, Brazil. Vet Parasitol 2004; 123(3-4): 161-166. PMid:15325042. http://dx.doi. org/10.1016/j.vetpar.2004.06.006

Gondim LFP, Barbosa HV Jr, Ribeiro Filho CHA, Saeki H. Serological survey of antibodies to Toxoplasma gondii in goats, sheep, cattle and water buffaloes in Bahia State, Brazil. Vet Parasitol 1999; 82(4): 273-276. http:// dx.doi.org/10.1016/S0304-4017(99)00033-3

Kamani J, Mani AU, Egwu GO. Seroprevalence of Toxoplasma gondii infection in domestic sheep and goats in Borno state, Nigeria. Trop Anim Health Prod 2010; 42(4): 793-797. PMid:19882227. http://dx.doi. org/10.1007/s11250-009-9488-3

Klun I, Djukovic-Djakovic O, Katic-Radivojevic SK, Nikolic A. Crosssectional survey on Toxoplasma gondii infection in cattle, sheep and pigs in Serbia: Seroprevalence and risk factors. Vet Parasitol 2006: 13(2): 121-131. PMid:16188388. http://dx.doi.org/10.1016/j.vetpar.2005.08.010

Langoni H, Greca H Jr, Guimarães FF, Ullmann LS, Gaio FC, Uehara RS, et al. Serological profile of Toxoplasma gondii and Neospora caninum infection in commercial sheep from São Paulo State, Brazil. Vet Parasitol 2011; 177(1-2): 50-54. PMid:21256676. http://dx.doi. org/10.1016/j.vetpar.2010.11.024

Lopes WDZ, Dos Santos TR, Da Silva RS, Rossanese WM, De Souza FA, Rodrigues JDF, et al. Seroprevalence of and risk factors for Toxoplasma gondii in sheep raised in the Jaboticabal microregion, São Paulo State, Brazil. Res Vet Sci 2010; 88(1): 104-106. PMid:19589550. http://dx.doi. org/10.1016/j.rvsc.2009.06.006

Masala G, Porcu R, Madau L, Tanda A, Ibba B, Satta G, et al. Survey of ovine and caprine toxoplasmosis by IFAT and PCR assays in Sardinia, Italy. Vet Parasitol 2003; 117(1-2): 15-21. PMid:14597274. http://dx.doi. org/10.1016/j.vetpar.2003.07.012

Moura AB, Osaki SV, Zulpo DL, Marana ERM. Ocorrência de anticorpos contra Toxoplasma gondii em suínos e ovinos abatidos no município de Guarapuava, PR, Brasil. Rev Bras Parasitol Vet 2007; 16(1): 54-56. PMid:17588324.

Ogawa L, Navarro IT, Freire RL, Oliveira RC, Vidotto O. Occurrence of antibodies to Toxoplasma gondii in sheep from the Londrina Region of the Paraná State, Brazil. Semina: Cienc Agrar 2003; 24(1): 57-62.

Pinheiro JW Jr, Mota RA, Oliveira AAF, Faria EB, Gondim LFP, Da Silva AV, et al. Prevalence and risk factors associated to infection by Toxoplasma gondii in ovine in the State of Alagoas, Brazil. Parasitol Res 2009; 105(3): 709-715. PMid:19468755. http://dx.doi.org/10.1007/ s00436-009-1472-3

Ramzan M, Akhtar M, Muhammad F, Hussain I, Hiszczyńskasawicka E, Haq AU, et al. Seroprevalence of Toxoplasma gondii in sheep and goats in Rahim Yar Khan (Punjab), Pakistan. Trop Anim Health Prod 2009; 41(7): 1225-1229. PMid:19225903. http://dx.doi. org/10.1007/s11250-009-9304-0

Rossi GF, Cabral DD, Ribeiro DP, Pajuaba ACAM, Corrêa RR, Moreira RQ, et al. Evaluation of Toxoplasma gondii and Neospora caninum infections in sheep from Uberlândia, Minas Gerais State, Brazil, by different serological methods. Vet Parasitol 2011; 175(3-4): 252-259. PMid:21075529. http://dx.doi.org/10.1016/j.vetpar.2010.10.017

Romanelli PR, Freire RL, Vidotto O, Marana ERM, Ogawa L, De Paula VSO, et al. Prevalence of Neospora caninum and Toxoplasma gondii in sheep and dogs from Guarapuava farms, Paraná State, Brazil. Res Vet Sci 2007, 82(2): 202-207. PMid:17266999. http://dx.doi.org/10.1016/j. rvsc. 2006.04 .001

Soares HS, Ahid SMM, Bezerra ACDS, Pena HFJ, Dias RA, Gennari SM. Prevalence of anti-Toxoplasma gondii and anti-Neospora caninum antibodies in sheep from Mossoró, Rio Grande do Norte, Brazil. Vet Parasitol 2009; 160(3-4): 211-214. PMid:19091473. http://dx.doi. org/10.1016/j.vetpar.2008.10.102

Ueno TEY, Gonçalves VSP, Heinemann MB, Dilli TLB, Akimoto BM, Souza SLP, et al. Prevalence of Toxoplasma gondii and Neospora caninum infections in sheep from Federal District, central region of Brazil. Trop Anim Health Prod 2009; 41(4): 547-552. PMid:18726165. http://dx.doi. org/10.1007/s11250-008-9220-8

Van Der Puije WNA, Bosompem KM, Canacoo JM, Wastling JM, Akanmori BD. The prevalence of anti-Toxoplasma gondii antibodies in Ghanaian sheep and goats. Acta Trop 2000; 76(1): 21-26. http://dx.doi. org/10.1016/S0001-706X(00)00084-X

Vesco G, Buffolano W, La Chiusa S, Mancusco G, Caracappa S, Chianca A, et al. Toxoplasma gondii infections in sheep in Sicily, southern Italy. Vet Parasitol 2007; 146(1-2): 3-8. PMid:17383099. http://dx.doi. org/10.1016/j.vetpar.2007.02.019 